\title{
THE USE OF TANGATA WHENUA AND MANA WHENUA IN NEW ZEALAND \\ LEGISLATION: ATTEMPTS AT \\ CULTURAL RECOGNITION
}

\section{Catherine Iorns Magallanes*}

This paper discusses the range of uses of the phrases tangata whenua and mana whenua in New Zealand Acts, the issues that have arisen as a consequence, and identifies some suggestions for addressing those issues.

\begin{abstract}
Most people find it impossible to separate language and identity. Language is perceived as the quintessence of a culture. It expresses a unique way of apprehending reality, capturing a world view specific to the culture to which the language is linked. But language is connected to identity in another important way: its presence and use in a community are symbolic of identity, emblems of group existence. Using a language is the ultimate symbol of belonging. ${ }^{1}$

Māori concepts hardly ever correspond exactly with those Western concepts which they appear, on the surface, to resemble. While there is a degree of overlap, there are usually divergences as well. Even if the denotation - the direct reference - is substantially the same, the connotations are significantly different. Commonly, several sentences of explanation are needed to deal adequately with the similarities and divergences. For these reasons it is unwise (though tempting for the sake of brevity)
\end{abstract}

* Senior Lecturer in Law, Victoria University of Wellington, BA, LLB (Hons) Well, LLM Yale. In 2005 the author was a consultant for Ross Philipson Consulting on the topic of Māori words referring to Māori in legislation.

1 René Dussault and others Report of the Royal Commission on Aboriginal Peoples (Minister of Supply and Services, Ottawa, 1996) vol 3 at s 2.3. 
regularly to translate the Māori word for a concept by a single English word or phrase, for listeners inevitably hear the English meaning. ${ }^{2}$

\section{INTRODUCTION}

In Aotearoa New Zealand the use of Māori words in legislation has become widespread. The primary reason for this use is to better recognise and legally provide for Māori culture and values. Part of accommodating Māori perspectives and culture in the law has been the use of terms in legislation which can better reflect the Māori concepts. It is thus perhaps not surprising that this use has increased steadily and significantly in the past 30 years, in tandem with the increasing wider societal acceptance and understanding of Māori language, culture and values. ${ }^{3}$

There are various different ways in which Māori words are used in legislation. The most common use is as a single Māori word or phrase within the English statute or regulation. This may be accompanied by an English definition or explanation of the term, but commonly is not. An increasing use is where an extensive passage of Māori text is used, such as in a preamble to a statute. This is commonly found in statutes with particular application to Māori such as Te Ture Whenua Māori Act 1993, the Māori Television Service (Te Aratuku Whakaata Irirangi Māori) Act 2003 and the legislation passed to implement settlements between Māori and the Crown over previous breaches of the Treaty of Waitangi.

The use of Māori terms, whether singly or as part of extensive passages, is an attempt to recognise and uphold Māori concepts and is thus part of an essential acknowledgement of the important place the concepts should have in New Zealand law and society. However, their use has not been without criticism or difficulty. At the simplest and most basic level, there have been

2 Joan Metge "Commentary on Judge Durie's Custom Law" (paper prepared for the Law Commission's Customary Law Guidelines project, 1996) at [2.4]. Metge provides an example: "For example, the common practice of translating "kaumatua" by the English "elder" has misled Pakeha into taking advanced age as the defining feature of this role, whereas to Maori the exercise of leadership functions is as if not more important." Metge elaborates further at [6.4.4]: "the concept kaumatua has five components, age plus social seniority plus life experience plus wisdom gained from reflecting thereon plus current occupancy of a position as leader to a group. Of these age is perhaps the least essential. True, the word 'elder' as used in English also has implications of experience and wisdom, but because of its form it is associated first and foremost with advanced age."

3 In 1996 the New Zealand Law Commission stated: "Maori is used increasingly in New Zealand statutes." (Law Commission Legislation Manual: Structure and Style (NZLC R35, 1996) at [190] [Legislation Manual: Structure and Style]). A 2001 report by the Ministry of Justice states: "Over recent years there has been a steady increase in Māori terms used in statutes." (Ministry of Justice He Hinatore ki to Ao Maori: A Glimpse into the Maori World (Ministry of Justice, 2001) at iii). The Law Commission also notes: "There was a discernible push from Maori and other quarters for Maori custom law to be applied in a number of different areas of general law, including family law, criminal justice, and administration of land." (Law Commission Maori Custom and Values in New Zealand Law (NZLC SP 9, 2001) at [117] [Maori Custom and Values in New Zealand Law]). 
difficulties with knowing what the words mean or encompass, and some errors have been made both in the choice of the words used in the legislation and by bodies applying them in practice. ${ }^{4}$ At a more fundamental level, their use has been criticised for, on the one hand, potentially subverting the fundamental principles of our legal system ${ }^{5}$ and, on the other, subverting the development of Māori cultural identity. ${ }^{6}$

An extremely significant piece of legislation incorporating te reo Māori kupu (Māori language expressions) is the Resource Management Act 1991 (RMA). It is significant primarily because of the visibility and primacy it gives to the substantive consideration of Māori interests and concepts. But it is also significant for the use of Māori kupu themselves: it was the first Act to use most of the Māori words it contains, and it illustrates some important issues relating to such use. ${ }^{7}$

I examine elsewhere the wide range of legislative uses of te reo Māori and the issues that these various uses raise. ${ }^{8}$ This paper focuses solely on the use of tangata whenua and mana whenua in New Zealand legislation. These terms have gained significant prominence due to their use in the RMA and other environmental and resource-related legislation. I suggest that, primarily as a result of the use of these terms in this high-profile legislation, the terms have become part of ordinary usage in law and the wider population. However, their use has not been without significant difficulty over their interpretation.

This article discusses the range of uses of these two terms, and the issues and difficulties they have raised. Interestingly, the most recent use has taken an approach which appears to avoid the primary criticisms of their earlier use. However, this recent use contains its own uncertainties, plus the particular focus of the legislation in question may make its approach harder to apply in other legislation.

4 The original definition of "kaitiakitanga" in the Resource Management Act 1991 provides the best example of this kind of error. The courts and local bodies applied the definition in an arguably unexpected manner (see Rural Management Ltd v Banks Peninsula District Council [1994] NZRMA 412 (PT)). It was subjected to considerable criticism. See Ani Mikaere's comment that it "points to the dangers of including Maori concepts in statute, thereby exposing them to misinterpretation and redefinition by institutions that have no appreciation of the cultural context in which those concepts have developed". Ani Mikaere "Maori Issues" [1994] NZ Recent Law Review 265, at 270. The legislation was amended as a result, with a replacement definition inserted by s 2(4) of the Resource Management Amendment Act 1997.

$5 \quad$ See Fiona Wright "Law, Religion and Tikanga Maori" (2007) 5 NZJPIL 261.

6 See Arnu Turvey "Te Ao Maori in a 'Sympathetic' Legal Regime: The Use of Maori Concepts in Legislation" (LLM Research Paper, Victoria University of Wellington, 2008).

7 The terms used in the Resource Management Act 1991 are "kaitiakitanga", "tangata whenua", "mana whenua", "tikanga", "wahi tapu", "mataitai", and "tauranga waka".

8 Catherine Iorns "The Use of Maori Words in Legislation: 'As a Maori I love it; as a Judge I Don't'" (2011) (forthcoming). 
The focus is on the use of these terms pepper-potted ${ }^{9}$ throughout English-language legislation, rather than on their use in extensive passages of Māori text. One reason for not focusing on the latter is that some of the difficulties identified with the use of Māori terms do not arise when they are included in these longer passages. The focus is also on uses in public statutes of general application. The use of these terms as proper nouns, in private statutes, or in public statutes of narrow or particular application (such as claims settlements Acts) is not examined. While the use of Māori in the settlement Acts is a source of much of the Māori used in legislation today, these Acts are designed to give effect to each particular settlement. They thus include matters which may be peculiar to each iwi or other Māori settlement entity, which is often not applicable to a wider context.

The paper identifies some suggestions for overcoming some of the difficulties identified and thus better achieving the aims and benefits of using te reo Māori kupu in legislation. It concludes with the paradox facing those who wish to use such terms or who have to interpret them once used.

\section{TANGATA WHENUA}

Tangata whenua was the one of the first terms to be used consistently in legislation and is now one of the most commonly used Māori terms in legislation. It appears from $1986,{ }^{10}$ mainly in legislation relating to land and natural resources (including environmental protection). It is perhaps not surprising that a more appropriate reference to the people themselves is one of the first changes to appear. This is similar to the change from the legislative use of Native to Māori ${ }^{11}$ - the right of a people or other cultural or ethnic group to call themselves by their own name is the most basic right of cultural identity and self-determination and is the easiest aspect to uphold and implement.

There are currently 38 statutes which use the term tangata whenua, 17 of which are claims settlement Acts. There appear to be two different types of uses of the term tangata whenua: one general, with a wide reference, and one specific, referring to a particular group of Māori.

9 I am using this term to describe the fact of "sprinkling" Māori terms throughout English language legislation; there is no normative or pejorative connotation in my use of it. This term originated in relation to housing, namely the practice of mixing lower income with higher income families, in an attempt to reduce class segregation and to create communities of people from different social classes. It was thus designed as a beneficial social policy. I note that, in New Zealand, the assimilationist "pepper-potting" of Māori housing in the 1950s and 1960s is now considered to have been a detrimental social policy (see for example Paul Meredith "Hopes and Reality: Housing" (2009) Te Ara <www.teara.govt.nz>), and the term is often used pejoratively in New Zealand.

10 It appears in legislation with earlier dates, such as the Marine Reserves Act 1971 and the Town and Country Planning Act 1977, but these uses were inserted by later amending legislation, both in 1987.

11 Most early legislation referred to "Native" or "Natives" instead of to " Māori". It was not until 1947 that the legislative switch was made to " Māori" so that new statutes did not use "Native" and existing references to "Native" were deemed to refer to " Māori". See Maori Purposes Act 1947. 


\section{A General}

One use is of general application, referring to Māori as tangata whenua, without definition of the term, and without obvious application of the statute in relation to land or resource management. It appears to be using "tangata whenua" as a synonym for "Māori", in an attempt to incorporate and be sensitive to Māori interests in general within the relevant legislation.

Some examples of this general approach are to be found in the Arts Council of New Zealand Toi Aotearoa Act 1994, the Families Commission Act 2003, and the Social Workers Registration Act 2003. For example, the Social Workers Registration Act states that the "aims and aspirations of Māori as tangata whenua, and the need for the appropriate involvement of Māori as tangata whenua, are integral and ongoing priorities" of the Social Workers Registration Board. ${ }^{12}$ The Families Commission is obliged to obtain the views of "Māori as tangata whenua."13

Even where the term has not been used in legislation, it has been used in this wider sense in the discussion of some Acts, such as in the explanatory note to the relevant Bill. For example, the Explanatory Note to the National Library of New Zealand (Te Puna Mātauranga o Aotearoa) Bill (subsequently enacted) at 2 explains that the reform of the previous 1965 Act provides an opportunity to address Māori interests:

The 1965 Act contains no reference to the interests of tangata whenua, in contrast to empowering legislation for comparative cultural institutions that has been passed since $1975 \ldots$. The Bill seeks to include the interests of tangata whenua by incorporating the existing Māori name of the National Library into the title. Thus, while the term "tangata whenua" is not used in the Act itself, the Explanatory Note illustrates how it is being used as a general term in ordinary language and arguably interchangeably with "Māori".

I suggest that the most interesting aspect of this general use - for the purposes of statutory interpretation - is that there is no definition of the term in the legislation. Instead, it is clearly assumed that the term is known well-enough to New Zealanders that a definition is not needed. The various issues that definition raises are discussed further below.

12 Social Workers Registration Act 2003, s 100.

13 Families Commission Act 2003, s 13. 


\section{$B$ Land and Resource Management}

The more common use of the term refers to tangata whenua in the context of land and resource management and related issues. ${ }^{14}$ This use does not refer to the interests of Māori generally, but to an identifiable and particular subset of Māori: those with traditional or customary authority over a particular geographical area. ${ }^{15}$

Most of these Acts use but do not define the term tangata whenua. The two notable exceptions are the RMA and the Fisheries Act 1996. Both of these Acts use the term tangata whenua extensively, typically in relation to identification of the relevant Māori group who has traditional or customary authority over a geographical area and for the purposes of consultation and participation in statutory procedures. Both statutes contain a definition of the term; notably, both utilise essentially the same definition (here from the RMA, s 2):

Tangata whenua, in relation to a particular area, means the iwi, or hapu, that holds mana whenua over that area.

Mana whenua means customary authority exercised by an iwi or hapu in an identified area.

There is no obvious discussion of these uses of the term tangata whenua in court decisions. The only discussion which has arisen has done so because of a debate over the interpretation of the term mana whenua which forms part of the definition of tangata whenua in the second, more particular sense.

There is discussion over the meaning of tangata whenua in the Report of the Waitangi Tribunal on Rekohu. ${ }^{16}$ The Tribunal notes that "'tangata whenua' is not customarily used to describe political power" and thus cannot be defined "by asking who has the customary authority in a place." ${ }^{17}$ It thus

14 General environmental or natural resource-related Acts which do so include (in alphabetical order): Biosecurity Act 1993, Conservation Act 1987, Crown Minerals Act 1991, Environment Act 1986, Environment Canterbury (Temporary Commissioners and Improved Water Management) Act 2010, Fiordland Marine Management Act 2005, Fiordland (Te Moana o Atawhenua) Marine Management Act 2005, Fisheries Act 1996 and the associated Customary Fishing Regulations, Hauraki Gulf Marine Park Act 2000, Historic Places Act 1993, Marine Reserves Act 1971, Maritime Transport Act 1994 (in relation to oil spills within the region of the relevant tāngata whenua), the Resource Management Act 1991 and the Waitakere Ranges Heritage Area Act 2008. A repealed statute which uses the term is the Town and Country Planning Act 1977, in relation to membership of regional planning committees. "A representative of the tangata whenua of the region" was inserted in 1987, without definition of the term. This Act was repealed by the Resource Management Act 1991.

15 This is discussed in more detail below in relation to "mana whenua", including how the reference to "authority" over an area as opposed to a wider relationship with it is considered too limiting and inaccurate.

16 Waitangi Tribunal Rekohu: A Report on Moriori and Ngati Mutunga Claims in the Chatham Islands (WAI 64 Ministry of Justice 2001).

17 Ibid, at 26. 
rejects the approach adopted in the RMA, which defines "tangata whenua" by reference to "mana whenua". This discussion thus also forms part of the discussion of mana whenua below.

\section{MANA WHENUA}

\section{A Legislation}

The first and preliminary point to note is that there is inconsistent spelling of the term across the statutes which refer to mana whenua. There are currently three general statutes which refer to mana whenua ${ }^{18}$ and four which refer to manawhenua ${ }^{19}$ (as common, not proper nouns). ${ }^{20}$ The definitions of the two terms in the various statutes are essentially the same. I thus group these together for the following substantive discussion.

As described above, the Fisheries Act 1996 and the RMA both refer to and define "mana whenua" in relation to the definition of "tangata whenua". The definition section is the only place in which the term mana whenua appears in these Acts; it is not also used later in the legislation - only tangata whenua is later used.

In contrast, the Conservation Act 1987 and the Reserves Act 1977 both require the Crown to "have regard to the manawhenua of the owner or lessee" in a review of Māori land for conservation purposes. They define "Manawhenua" in each respective s 2 as "customary authority exercised by an iwi or hapu or individual in an identified area." These definitions and references were inserted in March 1993 by amendments to the relevant Acts. The Walking Access Act 2008 adopts a similar definition but includes it in the section itself rather than in a separate definition section: the New Zealand Walking Access Commission, in naming a walkway over public land, must take account of views of "hapu or iwi that have manawhenua (customary authority over land) in the area in which the walkway is located."21

The other statutes which use these terms are claims settlement Acts which are not the focus of this article. However, many of the statutes refer to the first version of the spelling of the term and some refer to the second. ${ }^{22}$ Some of these references are as part of Māori text, some use the Māori

18 These are the Fisheries Act 1996, the Resource Management Act 1991 and Local Government (Auckland Council) Act 2009 (as inserted in a 2010 amendment). The Local Government (Tamaki Makaurau Reorganisation) Act 2009 also used "mana whenua" but is now repealed.

19 These are the Reserves Act 1977 and the Conservation Act 1987, both as inserted in 1993 amendments, plus the Walking Access Act 2008.

20 The Maori Fisheries Act 2004, sch 4 refers to proper names of Māori authorities which include "Manawhenua" in their titles.

21 Walking Access Act 2008, s 23(2)(a).

22 There are 14 claims settlement Acts which use "mana whenua" and five which use "manawhenua". 
term in the middle of English text, ${ }^{23}$ and some have both. I presume that the reason for these different uses is personal choice of the iwi concerned.

It is not so clear why the general statutes use the different versions. It does not appear to be due to the time of enactment, as the first version was adopted in 1991, 1996 and 2010, while the second version was adopted in 1993 and 2008. It may simply be due to the approach of the minister responsible. For example, the Conservation, Reserves and Walking Access Acts were all prepared by the Department of Conservation while the other Acts were not. ${ }^{24}$

Of further interest, as described above, is the fact that the Conservation Act is one of the Acts which uses the term tangata whenua. ${ }^{25}$ However, while it defines the term manawhenua in s 2 of the Act, it does not also include a definition of tangata whenua, as the Fisheries Act and RMA do. There is thus no explicit link between the use of the term tangata whenua in the Conservation Act and its use of - or the meaning of - manawhenua.

\section{B Application}

The meaning of the term of mana whenua in legislation has been the subject of discussion by the Waitangi Tribunal and the Environment Court, in respect of its use in the RMA. The concern of the Tribunal and thus the Court is that it is inappropriately used in the RMA. It is not a traditional Māori concept and the way it is used in the legislation is at odds with the development of the concept.

The Waitangi Tribunal accordingly disapproves of the use of the term mana whenua generally, and particularly disapproves of its use as part of the definition of tangata whenua in the Resource Management Act: ${ }^{26}$

The term "Mana whenua" appears to have come from a nineteenth-century Māori endeavour to conceptualise Māori authority in terms of the English legal concepts of imperium and dominium. It links mana or authority with ownership of the whenua (soil). But the linking of mana with land does not fit

23 See Ngāi Tahu Claims Settlement Act 1998, Schedules. Some Schedules simply use the term "manawhenua" without definition in a sentence: "Victory in this battle saw Ngai Tahu gain manawhenua in the area." (sch 25). Others use it with a definition: "Manawhenua (tribal authority over the area) was gained ... " (sch 38), or "The Kati Kuri hapu of Ngai Tahu has manawhenua (tribal authority over land) by way of ..." ( $\operatorname{sch} 67)$.

24 The Conservation Act 1987 and the Reserves Act 1977 are both administered by the Department of Conservation. The Walking Access Act 2008 transferred the responsibilities under the Act from the Department of Conservation to the New Zealand Walking Access Commission.

25 In relation to the membership of Conservation Boards see Conservation Act 1987, s 6P.

26 Waitangi Tribunal, above n 16, at 28-29. These Crown submissions include helpful detail of evidence of the historical uses of "mana whenua" (or "manawhenua") and are worth reading in their own right. See "The Interim Closing Submissions of the Crown to Claim by Te Iwi Moriori Trust Board and Tchakat Henu Society (Wai 64 and 308)" (WAI 64 DOC G15 Ministry of Justice 2001) at [22-43]. 
comfortably with Māori concepts. Recent research tends to agree that the term "mana whenua" itself does not appear in the early records about customary rights to land. ... These opinions confirm that the term "mana" was personal and was used in regard to the influence authority of chiefs. Other opinions compiled in the Appendix consider that mana whenua was a nineteenth-century invention. Crown counsel likewise challenged - we think correctly - its use to describe the general authority of a particular group over any area of land.

We are inclined to think that the term "mana whenua" is an unhelpful 19th century innovation that does violence to cultural integrity. However, subject to such arrangements as may have been settled by the people themselves, our main concern is with the use of the words "mana whenua" to imply that only one group can speak for all in a given area when in fact there are several distinct communities of interest, or to assume that one group has a priority of interest in all topics for consideration. Some matters may be rightly within the purview of one group but not another.

This criticism of the use of the term "mana whenua" as part of the definition of the term "tangata whenua" has also been adopted by the Environment Court. The Court concluded that it was not appropriate to use the term Manawhenua Iwi in a District Plan. ${ }^{27}$ The Court adopted the criticisms made by the Waitangi Tribunal of the term mana whenua and considered that the use of the term as a proper noun, Manawhenua, did not resolve the concern over the exclusivity implied.

Justice Durie has commented extrajudicially that one way in which the term was used historically, not only implied exclusivity, but it also implied exclusivity in a negative way - that is, the term was used in order to assert control to the exclusion of others, often at the beginning of a war or other dispute over the resource in question. It was thus not a term to be used in a peaceful context such as in legislation. ${ }^{28}$

The criticism of the term by both the Tribunal and the Environment Court suggests that, at the very least, the term should not be used as part of any definition of tangata whenua and that it should not be used in respect of land and resources. The Tribunal and Justice Durie have also gone further than that and suggested that use of the term is not helpful at all, in any context. It would thus be helpful to know why it was included in the RMA. Any future guidelines should consider whether to recommend the term's useage in future legislation and, if it be used, in what circumstances that might be appropriate.

Perhaps what is most interesting in terms of legislative use is that, despite the existing and wellknown criticism, no effort has been made to amend the legislation in question. Moreover, the term

27 Golden Bay Marine Farmers v Tasman District Council EC Wellington W19/2003, 27 March 2003 at [255].

28 Meeting between Edward Durie, members of the Law Commission, members of Te Puni Kōkiri and of Ross Philipson Consulting (31 May 2005) (notes on file with the author). 
continues to be used in new legislation. ${ }^{29}$ The most notable recent example is that it was used in the 2009 legislation establishing the Auckland super-city council. ${ }^{30}$

\section{Auckland City Council 2010}

The 2010 amendment to the legislation establishing the Auckland Council establishes an advisory board to the Auckland Council with the following purpose: ${ }^{31}$

to assist the Auckland Council to make decisions, perform functions, and exercise powers by-

(a) promoting cultural, economic, environmental, and social issues of significance for-

(i) mana whenua groups; and

(ii) mataawaka of Tamaki Makaurau; and

(b) ensuring that the Council acts in accordance with statutory provisions referring to the Treaty of Waitangi.

The interpretation section interestingly defines not mana whenua but mana whenua group, and uses mana whenua as part of that definition. It provides: ${ }^{32}$

mana whenua group means an iwi or hapu that-

(a) exercises historical and continuing mana whenua in an area wholly or partly located in Auckland; and

(b) is 1 or more of the following in Auckland:

(i) a mandated iwi organisation under the Māori Fisheries Act 2004:

(ii) a body that has been the subject of a settlement of Treaty of Waitangi claims:

(iii) a body that has been confirmed by the Crown as holding a mandate for the purposes of negotiating Treaty of Waitangi claims and that is currently negotiating with the Crown over the claims.

29 It has been used in claims settlement legislation since the criticism. See the Ngaa Rauru Claims Settlement Act 2005, the Ngati Awa Claims Settlement Act 2005, the Ngati Mutunga Claims Settlement Act 2006 and the Central North Island Forests Land Collective Settlement Act 2008. However, individual uses may be in line with the use of the iwi concerned, so may not be indicative of nor provide a helpful precedent for wider use.

31 Ibid, s 81.

32 Ibid, s 4. 
This definition is different to that use in the RMA. The definition of mana whenua group may encompass a slightly different range of groups than would be covered by the concept of mana whenua provided in the RMA. It is likely that in many situations, they would be the same; but the two cumulative requirements would presumably narrow its coverage (or else the second would be redundant).

These Auckland Council Acts contain the first legislative use of mataawaka and it is not a term in common normal usage. It has been defined in the Act (also in s 4) as meaning "Māori who (a) live in Auckland; and (b) are not in a mana whenua group." I suggest that this term has been used in order to reflect the fact that there are many Māori in Auckland who are entitled to representation as Māori, but who are not affiliated with or participate within an Auckland-based iwi or hapu. In terms of interpretation issues, is most helpful that the definition was provided.

From the point of view of legislative drafting, it is interesting that mana whenua was used, given the previous criticism of it. For example, the Parliamentary Counsel Office (PCO), which is responsible for drafting legislation, is well aware of the criticism of the use of mana whenua and is likely as a result to have discouraged its use. However, the role of PCO is advisory and the ultimate choice as to the terms used is up to the minister sponsoring the Bill. In this case, I note that the Royal Commission on Auckland Governance used the term mana whenua in their report which recommended the establishment of the new Auckland Council. ${ }^{33}$ Moreover, the Royal Commission explicitly considered the terminology it preferred to use. While the Commission's recommendations in respect of Māori representation were not followed, ${ }^{34}$ it appears likely that the legislation used the same term either because - or for the same reasons that - it was used in the Report.

The Commission distinguished between two different "broad categories" of Auckland Māori. ${ }^{35}$ One category is mana whenua Māori and the other is non-mana whenua, taura here or urban Māori. The Commission helpfully defined both categories for the purposes of its Report. The difference between the two categories is the location of ancestral ties: "mana whenua" are "local Māori with ancestral ties to the region"36 or "Māori who have ancestral rights to occupy the Auckland region or part of it; namely, their tribal rohe fall within the Auckland region. ${ }^{37}$ In contrast, the "non-mana

33 Peter Salmon, Margaret Bazley and David Shand Report of the Royal Commission on Auckland Governance (2009).

34 The Commission recommended that three seats be reserved for Māori representatives: two Auckland City councillors "elected by voters on the Māori electoral roll" and one councillor "appointed by mana whenua". Ibid, at [42] and 497.

35 Ibid, at [22.11].

36 Ibid, at [22.6].

37 Ibid, at [22.11]. 
whenua" category is for "Māori who may live in a certain area but have ancestral ties to another region." 38

The Commission explicitly considered whether to use the term tangata whenua and rejected it: ${ }^{39}$

the Commission has tried to avoid this terminology in its report, as the term "tangata whenua" can also

be used in a broader sense to mean all Māori, on the basis that at a national level, Māori are the tangata

whenua of New Zealand.

The Commission also noted the difficulty that had arisen with determining "which groups qualify for mana whenua status in the Auckland region." 40 While some groups would clearly qualify, it noted the "many competing and conflicting claims" due to historical settlement patterns. ${ }^{41}$ However, this difficulty was founded purely on the factual basis for application of the given interpretation of mana whenua; there was no reference to any differences in or difficulties with the definition itself. For example, there was no reference to the Tribunal's criticism of the use of the term tangata whenua in the RMA, discussed above. ${ }^{42}$ I note that, before writing their report the Commission consulted on how best to get Māori input into the report, prepared a specific document on Māori representation issues and called for submissions on it, and held hui with "mana whenua groups" and "urban Māori" in the region. ${ }^{43}$ It is thus likely that the Commission's use is reflective of the local use of the term.

From a statutory interpretation perspective, the approach taken in the Auckland Council legislation to the interpretation of mana whenua is interesting for a number of reasons. The first and most obvious is in relation to the substance of the definition or interpretation taken. It is clear that the Royal Commission's focus on ancestral ties is close to, but different from, the statutory definitions considered above, which refer to customary authority over an area. Further, it appears that the Royal Commission's approach avoids the criticisms levelled at the meanings used in the RMA - it was precisely the focus on authority which was criticised.

38 Ibid, at 478. A more detailed definition is given in at [22.11]:

Non-mana whenua or taura here Māori: Māori who do not identify with any of the mana whenua groups in the Auckland region. They may identify with iwi or hapū whose tribal rohe are elsewhere in New Zealand, or they may not have any particular tribal affiliations. They are sometimes referred to loosely as "urban Māori". In the Auckland region, taura here greatly outnumber mana whenua Māori.

39 Ibid, at [22.11].

40 Ibid, at [22.12].

41 Ibid, at 479. The Commission cited Waitangi Tribunal "The Tāmaki Makaurau Settlement Process Report" (WAI 1362 Ministry of Justice 2007) at 13.

42 See Waitangi Tribunal, above n 16 and accompanying text.

43 Salmon, Bazley and Shand, above n 33, at [22.6]-[22.9]. 
However, this meaning is neither apparent on the face of the statute, nor is there any discussion of it in the Explanatory Note to the Bill or other official parliamentary materials. ${ }^{44}$ Anyone wishing to find out that this is the approach taken in this Act needs to go back to the Royal Commission's Report. The utilisation of such legislative reform materials is permissible in interpreting statutes. However such pre-parliamentary materials are not as reliable as later sources, mainly because government and parliamentary purposes may have changed since such reports, so that the resulting legislation might not reflect the reform recommendations. ${ }^{45}$ Further, it might not occur to a person reading the statute to consult the Report, in order to determine the meaning of a statutory term. It is thus not helpful to rely on such extrinsic material.

Of more concern is that the meaning adopted is different from the meaning used in existing statutes, when this has not been explicitly identified. While the existing meaning of mana whenua has been criticised, it has not been changed in existing statutes and is well-known in the environmental and resource management area. Without a definition in the Auckland Council legislation, given the past history of litigation over the meaning of Māori terms in legislation, it is quite possible that this meaning will also be litigated.

There is one aspect of the definition of mana whenua group in the Auckland Council legislation which will be helpful in avoiding the kind of litigation seen in respect of other Māori terms. While the legislation has not defined mana whenua, it has very carefully delineated the range of groups who can qualify, including an additional requirement that the group must also be one of the existing bodies mentioned, thus already recognised by the Crown. ${ }^{46}$ This will narrow the kind of argument which can be made about what body can be a mana whenua group. Further, I note that the type of application of this legislation is unlike that under the RMA: the RMA tries to identify the primary body that has the right to be consulted on and make submissions on relevant resource management issues. There can thus be tensions over competing interests. The same exclusivity is not entailed in the case of the Auckland Council advisory board, which is attempting to make sure that all are represented.

44 The Explanatory Note to the Local Government (Auckland Law Reform) Bill 2009 does not address the choice of terms used. In respect of the new provisions establishing the Māori advisory board it merely says that the Bill inserts a new part "relating to" "the establishment and operation of a board promoting issues of significance for mana whenua and Māori of Tamaki Makaurau". See Local Government (Auckland Law Reform) Bill 2009 (112-1) (explanatory note) at 6.

45 As is evident, for example, in the substance of the mechanisms for Māori representation on the Auckland Council. This issue of Māori representation on the Council was highly contested and the government went against the recommendations of the Royal Commission which recommended establishing the new Council in the first place. Māori representation was the subject of much political debate, consultation by government and submissions by Māori.

46 See above n 30 and accompanying text. 
Thus, is interesting that the approach taken to the use of mana whenua in the recent Auckland Council legislation is a different one from that used to date, particularly that used in the RMA. It may be that the different context of the Auckland Council legislation means that the same kinds of problems as have arisen in respect of the RMA will not arise. However, ultimately, it may also be that the use here is most reflective of the local situation and thus cannot be considered as helpful for general Acts as it might appear.

\section{ISSUES}

The use of Māori words in legislation, with and without definitions, raises various issues. The first, preliminary issue concerns denotation, as raised by the different uses of mana whenua and manawhenua. I suggest that, for general statutes, it would be sensible to use the same spelling of a concept. At the very least, the difference makes it difficult to find all the uses of a term, in this day and age of electronic information retrieval where precise spelling of a term is required. It seems like the kind of matter for which drafting guidelines would be appropriate, perhaps developed through bodies such as the PCO and the Māori Language Commission.

I note that the Law Commission's Legislation Manual has suggested uniformity in the approach to denotation of lengthened vowels (using macrons instead of double vowels), for uniformity's sake. ${ }^{47}$ While this advice is not always followed, ${ }^{48}$ it does appear to be sensible.

The second issue raised is in relation to the definition of Māori terms. For statutory interpretation purposes, certainty of meaning and application of the law is preferable. While judges are expected to rely on their general linguistic competence in interpreting statutes, it is not necessarily the case that all those who will need to interpret and apply it will have the necessary familiarity with or understanding of the concepts. The more complex the term - and the more reflective it is of Māori culture - the more such an ability is necessary under this general approach to statutory interpretation. If they do not have competence in respect of Māori terms, then either a definition needs to be provided or assistance will be required by way of expert evidence (or both).

I suggest that, in the case of the general use of tangata whenua, especially given the phrase it appears in - Māori as tangata whenua - this meaning is well and widely understood. However, it is perhaps not so well-known for the more complex mana whenua (and thus for tangata whenua in its narrower sense). This may well be a situation where a definition would be helpful.

The definition in the Auckland Council legislation is particularly helpful, as it defines it comparatively precisely, for the purposes of that statute. Similarly, mataawaka is a term which is not

47 Legislation Manual: Structure and Style, above n 3, at [195].

48 For example, the Auckland Council legislation refers to "mataawaka" with a double vowel (see Local Government (Auckland Council) Act 2009, s 81.). While this difference might be explained by deference to the linguistic practice of the Auckland region, this goes against the Law Commission's recommendation. 
well-known and it provides a helpful example of the utility of providing a definition in such cases, so its scope is clear and the application of the category is certain.

Despite these useful examples, there are drawbacks to the inclusion of definitions of Māori terms. For example, the author recalls that, when Māori words were first being considered for use in legislation, definitions were rejected by Māori on ideological or cultural grounds. As Metge notes in relation to difficulties in interpreting Māori words in legislation: ${ }^{49}$

Attempts to get around this problem by defining the Māori word in the Interpretation section of a Bill

are resented by Māori because they pre-empt the authority of Māori pukenga and 'fix' a meaning that

may be wrong or in the process of change.

If a definition is included, it needs to be accurate and adequately convey the Māori concept. There are difficulties with this in practice, such as in the difficulty of finding the appropriate English words to convey the relevant Māori concept. ${ }^{50}$ Thus, it is possible that a statutory definition could be too simplistic and unable to adequately explain the term. This is because the concept's interpretation in its cultural context entails far more detail and related aspects than the English concepts can convey. ${ }^{51}$

This problem of correspondence is more fundamental, and particularly a problem when individual words are used outside of their natural linguistic context - that is, pepper-potted amongst English words. This can be overcome, with accurate expert advice on the concepts and words to use. However, the discussion of mana whenua illustrates how mistakes can be made through choosing the wrong terms.

The use of mana whenua in legislation may also illustrate how modern usage can modify traditional meaning. Metge has identified this as a problem with other words, as a result of their use in legislation. ${ }^{52}$ The use in the RMA is considered incorrect, yet it has not been altered and is still applied today. It is possible, given the scope and breadth of its application under the RMA, that this will come to be the accepted meaning.

49 Metge, above $\mathrm{n} 2$, at [2.5].

50 It has been commonly noted that there is often little or no correspondence between Māori and English terms or concepts. See Metge, above $\mathrm{n} 2$ and accompanying text. See also the discussion by the Waitangi Tribunal of this contrast between English and te reo Māori in Waitangi Tribunal Motunui Waitara Report (WAI 6 Department of Justice 1983) at [10.2].

51 This has been said of the definition of "kaitiakitanga" in the Resource Management Act 1991. See Report and Recommendations of the Board of Inquiry into the New Zealand Coastal Policy Statement (Department of Conservation 1994) at 4.

52 See her discussion of the "loose" use of "kaupapa" today "to convey a multitude of meanings" in Metge, above $\mathrm{n} 2$, at [2.11.3]. 
These drawbacks with definition have led many to suggest not defining them at all in legislation. For example, the Law Commission recommended that Māori terms should only be defined "if they are to be given a specific meaning for the purpose of that Act; otherwise their meaning might be narrowed (or widened) unintentionally." ${ }^{53}$ Even in respect of using "a Māori term which is not commonly understood" the Law Commission suggests that "it may be better not to provide any English equivalent or explanation in the text, but to leave it for judicial interpretation. "54

Litigation is not normally the best way to determine the scope of a term in legislation. This makes the application of the law uncertain, slow and expensive even more so if lawyers, judges and policy-makers do not understand the scope of the terms themselves. ${ }^{55}$ As mentioned already, general linguistic competence may not be enough for the interpretation of Māori terms, especially when the meaning of words may depend on a cultural context with which judges may be unfamiliar. Indeed, the Law Commission suggests that some such terms "cannot be applied without a knowledge of Tikanga Māori"56 and recommends that judges receive "the assistance of expert evidence. ${ }^{57}$ Metge agrees with the need for expert "assistance of pūkenga" with such matters. ${ }^{58}$

Judges have extensive experience in evaluating the strength of expert witnesses, and the courts have shown themselves able to consider the relevant points of view and come to a determination on the evidence about the likely meaning and application of a Māori term, even one with a significant spiritual and/or cultural component. ${ }^{59}$ However, the lack of judicial expertise in the scope and meaning of traditional Māori words and concepts does make this a hard road to follow. Clearly the

53 Legislation Manual: Structure and Style, above n 3, at [193].

54 Ibid, at [194].

55 A good example of this is litigation over the meaning of wāhi tapu. The Environment Court, in deciding whether to uphold Māori objections to proposed development adversely affecting wahi tapu, has had to decide what a wāhi tapu is before they can decide whether it exists in the case before it. The Court considered dictionary definitions, reports of the Waitangi Tribunal, definitions in relevant Resource Management Act 1991 instruments and other legislation forming part of the statutory scheme, in addition to considerable expert testimony from both sides. For more discussion of this example, see Robert Joseph "The Interface Between Maori Custom and State Regulatory Systems" (Research Paper, Te Mātāhauariki Research Institute, 2007) at 5-6.

56 The Law Commission report raises the issue of judicial competence in this respect. See Maori Custom and Values in New Zealand Law, above n 3, at [228].

57 Legislation Manual: Structure and Style, above n 3, at [194].

58 Metge, above n 2, at [2.9.11].

59 See above n 55. 
easiest step to take in improving this process is better education of those who need to apply and interpret the legislation in such Māori culture and concepts. ${ }^{60}$

The more difficult solution would be to require greater cultural ownership of the process by Māori. This would entail structural change so as to achieve greater and more direct Māori involvement at all levels of legislative decision-making and application. However, the benefit would be that, as well as achieving more accurate creation and application of relevant laws, this would address the more fundamental criticism that the use of Māori concepts in legislation can subvert them through interpretation by state institutions. ${ }^{61}$ It would be ironic and rather sad if a measure designed to facilitate Māori cultural preservation or self-determination instead ended up subverting it.

\section{CONCLUSION}

The increasing use of te reo Māori in legislation has been both a political recognition of the importance of te reo itself, as well as a recognition that the Māori term is likely to better reflect the substance of the concept to be upheld in the legislation. Overall, it was this move toward such socially inclusive laws and policies - one that was thought to better actualise the Treaty of Waitangi partnership $^{62}$ - that produced the use of Māori terms in legislation.

However, this raises various issues of difficulty with interpretation as well as with definition of the terms and concepts to be incorporated. The uses of the many different words incorporated have varied and different words have given rise to different difficulties. The examples of tangata whenua and mana whenua discussed in this paper have illustrated the difficulty of definition and that it is possible to get it wrong.

There are three methods suggested which could overcome the worst of these problems. The first and most obvious is to achieve accuracy in definition, where a definition is appropriate. But that still leaves many situations where it may not be so appropriate, and can thus entail difficulties in

60 For example, I note that both the New Zealand Law Commission and the Ministry of Justice have, with this aim, produced publications concerning the incorporation or inclusion of Māori custom in New Zealand law. See Maori Custom and Values in New Zealand Law, above n 3, at [127], and Ministry of Justice, above n 3. This has also been the subject of judicial training.

61 This argument is made by Turvey, above n 6, at 45. For example, Turvey comments that the terms are used and "interpreted in accordance with the underlying values and interests of the dominant group" which will "inevitably result in falsely constructed representations of Māori culture".

62 This view has been adopted as the basis for a significant research project, the Laws and Institutions for Aotearoa/New Zealand by the Te Mātāhauariki Research Institute, based at Waikato Law School. The aim of this project is "the establishment of socially inclusive laws and political and legal institutions in Aotearoa/New Zealand that actualise the partnership explicit and implicit in the Treaty of Waitangi" (see Robert Joseph "Comparatively Speaking: A Summary Paper for Objective 2" (Occasional Paper, Te Matahauariki Institute, 2003) at 3). The Law Commission has endorsed this view Maori Custom and Values in New Zealand Law, above n 3, at viii. 
interpretation after enactment. The simplest method to overcome this, and one which has already begun, is the education of those who have to apply and determine the meanings of the legislation in Māori culture, customs and values. The more difficult solution - that of requiring greater cultural ownership of the process by Māori - has been debated more generally in respect of Māori decisionmaking at all levels of government. There have been some successes at the wider level - such as the adoption of the Whānau Ora policy, entailing much greater involvement of Māori in decisionmaking in this area. However, there have also been setbacks. I suggest that the Auckland Council legislation illustrates the political difficulty in achieving greater Māori involvement in decisionmaking: even though its use of Māori terms in this legislation adopts a helpful approach, the refusal for political reasons to adopt the substantive proposals in respect of guaranteeing Māori seats on the new Council necessarily limits Māori involvement in decision-making at higher levels.

In conclusion, I suggest that the use of the two terms studied in this paper, across different laws, illustrates and encapsulates the difficulties with the use of Māori words in legislation. The need for certainty suggests the adoption of legislative definitions, while the need for cultural respect and accuracy suggests flexibility and the need to not define the Māori terms used. The latter creates uncertainty in the process, method and result of interpretation, and of the place of Māori knowledge and thus people within that process. It certainly puts legislative drafters between a rock and a hard place. It is perhaps not surprising that Justice Durie said, of the use of Māori words in legislation: "As a Māori I love it; but as a Judge I don't."63

63 Edward Durie, above n 28. 